\title{
Bladder Cancer pN3 TNM Finding v8
}

National Cancer Institute

\section{Source}

National Cancer Institute. Bladder Cancer pN3 TNM Finding v8. NCI Thesaurus. Code C140412.

Bladder cancer with lymph node metastasis to the common iliac lymph nodes. (from AJCC 8th Ed.) 